\title{
Symbiosis of nodule bacteria with perennial xerophyte leguminous plants of Central Asia
}

\author{
Zair S. Shakirov*, Sardor A. Khakimov \\ Institute of Microbiology of Uzbekistan Academy of Sciences, Tashkent, Republic of Uzbekistan; *Corresponding Author: \\ zair@dostlink.net
}

Received 27 April 2010; revised 3 May 2010; accepted 5 May 2010.

\section{ABSTRACT}

From nodules of perennial xerophyte desert leguminous plants - Ammodendron conollyi, Astragalus villossimus, Astragalus unifoliolatus - 151 bacterial isolates have been isolated. The study of nodulation showed that AC8-1, AC11, AC21, AC1-1, AC12-1 isolates (from Ammodendron conollyi), AV1, AV8-1, AV9, AV26-1, AV36-1 isolates (from Astragalus villossimus) and AU17-1, AU30-1, AU30-2, AU20-1, AU23 isolates (from Astragalus unifoliolatus) formed an effective nitrogen-fixing symbiosis with the host plants. As a result of $16 \mathrm{~S}$ rRNA gene study of the salt-resistant nodule bacteria it has been determined that bacteria were related to Rhizobium, Burkholderia and Achromobacter genera. The study of isolates growth has revealed that there were fast-growing and moderately-growing isolates that possessed with doubling-time varying from 20 to $\mathbf{4 5} \mathrm{min}$. Their examination for antibiotic-resistance showed that the number of bacterial colonies of selected strains decreased to some extent in the presence of chloramphenicol, but in all strains the resistance to antibiotics was detected. The further investigations of resistance of the formed symbiosis to stresses (drought, salinity) showed that at $6.41 \%$ of moisture the maximal height and biomass of inoculated plants of Ammodendron conollyi were $21 \mathrm{~cm}$ and $2320 \mathrm{mg}$, but at $3.8 \%$ moisture the height reduced by 4 times (up to $4.5 \mathrm{~cm}$ ) and the biomass - by 11 times (203 $\mathrm{mg}$ ). The analogous effect was observed in Astragalus villossimus and Astragalus unifoliolatus symbiosises. The salinity equal to $100-200 \mathrm{mM} \mathrm{NaCl}$ did not affect practically on normal growth and development of desert leguminous plants symbiosis, while for Astragalus villossimus such affecting concentration comprised up to $100 \mathrm{mM} \mathrm{NaCl}$. The light microscopy and electron microscopy of Astragalus villossimus nodule sections showed that V1 nodule bacteria strain efficiently colonized the internal space within nodules, where they were transformed into bacteroids. At $100 \mathrm{mM}$ $\mathrm{NaCl}$ salinity concentration the colonization of nodule bacteria within nodule plant cells reduced in comparison with control nodules of plants grown in non-salted conditions.

Keywords: Ammodendron conollyi; Astragalus villossimus; Astragalus unifoliolatus; Nodulation; Nitrogen Fixation; Salinity; Bacteroid; Rhizobium; Burkholderia; Achromobacter

\section{INTRODUCTION}

Deserts occupy one of third of dry land and they are unclaimed potential for conducting human's economical activity. In many regions the desertification process with its spreading to arable lands is going on, so the problem of combating desertification is actual for many countries.

Desert legumes are represented with annual plants and perennial trees and shrubs, which serve as a frame basis for desert ecosystem. There are literature data about symbiosis of relatively hygrophilous acacia trees with their nodule bacteria [1,2], but there is a few data about development of nitrogen-fixing symbiosis of xerophyte desert legumes, their nodule bacteria and nodulation. Nodulation in hygrophilous Acacia auriculiformis and Acacia ampliceps reduced during the change of moisture content from $0.008 \mathrm{MPa}$ to $0.08 \mathrm{MPa}$ twice and totally disappeared at $0.8 \mathrm{MPa}$ [1]. Under inoculation of saltresistant Acacia ampliceps species by salt-tolerant strain of nodule bacterium the nitrogen-fixing activity of formed symbiosis considerable increased in the presence of salt in comparison with nitrogen-fixing activity of symbiosis caused with inoculation by salt-intolerable strain [1]. In 20 Acacia species nodules formed after 5 months of growth, but in Leucaena leucocephala the formation of nodules was stimulated by low doses of nitrogen fertilizers (30-50 kg/Ha) and suppressed with 
high doses (100 kg/Ha and more) [1]. More humid sands promoted the increase of nodulation frequency in Prosopis glangulosa (honey mesquite), desert perennial leguminous shrub/tree. Rhizobia, isolated from Acacia, Prosopis and Leucaena were resistant to $500-850 \mathrm{mM}$ $\mathrm{NaCl}$ [2]. For the most of rhizobia the optimal temperature for growth in culture varies within range $28-31^{\circ} \mathrm{C}$, however, some strains of rhizobia isolated from woody legumes of Acacia and Prosopis species grew well at $40-44^{\circ} \mathrm{C}$ [2]. The growth of plants, their nodulation and nitrogen fixation (nitrogen content) in Acacia redolens and Acacia cyclops, inoculated with salt-resistant nodule bacteria, grown in vegetation experiments within sand, were observed up to salinity value $80 \mathrm{mM} \mathrm{NaCl}$, but in Acacia ampliceps plants during growing within sand up to $200 \mathrm{mM} \mathrm{NaCl}$ [2]. Bacterial cells of rhizobia from Acacia nilotica displayed the stable growth up to 850 $\mathrm{mM} \mathrm{NaCl}$ and formed effective nitrogen-fixing nodules in Acacia trees at $150 \mathrm{mM} \mathrm{NaCl}$ [2].

The objects of the present research were microbiological and symbiotic properties of nodule bacteria isolated from Ammodendron conollyi ("sandy acacia", tree), Astragalus villossimus (shrub) and Astragalus unifoliolatus (sandy semi-shrub), xerophyte perennial leguminous plants of Kyzylkum desert (Uzbekistan) that grow at average annual rainfall norm $60 \mathrm{~mm}$ and temperature $45-50^{\circ} \mathrm{C}$ [3], and also the host specificity of their nitrogen-fixing symbiosis towards to host plant as well as resistance of their symbiosis to stresses (salinity, drought).

\section{MATERIALS AND METHODS}

\subsection{Description of Ammodendron conollyi, Astragalus villossimus, Astragalus unifoliolatus plants}

Ammodendron connollyi Bge. ("sandy Acacia”) belongs to Leguminosae family and Ammodendron genus. It looks like a shrub (in juvenile state), later (after 3-4 years) it turns into tree that in mature state can reach of height 2-3 $\mathrm{m}$ and maximal height - up to $8 \mathrm{~m}$ [3].

Astragalus villossimus Bge. belongs to Leguminosae family and Astragalus genus, Cercidothrix subgenus, Ammodendron Bge section. It is a branched shrub with height up to $70 \mathrm{~cm}$ and surface with white hairs. Woody branches are long and thick; they are covered with light splintered bark. Annual stems (branches) are either very short or long (6-23 cm length), they twine round and, they are fluffy and white [3].

Astragalus unifoliolatus Bge. belongs to Leguminosae family, Astragalus genus, Cercidothrix subgenus, Ammodendron Bge. section. It is a shrub with woody stem (trunk). Annual branches are long, branchy, 13-22 cm length, cylindrical, closely twisted, white [3].

\subsection{Nodule Sampling and Isolation of Nodule Bacteria}

Nodules were sampled during intense blossoming and repeatedly rinsed with sterile distilled water, then they were sterilized in $96 \%$ ethanol with followed their burning in open flame. Bacterial isolates of nodule bacteria were isolated from nodules and purified in correspondence with common methods [4,5], then they were re-sowed to medium of the following composition $(\mathrm{g} / \mathrm{L})$ : glucose -5 , sucrose $-5, \mathrm{~K}_{2} \mathrm{HPO}_{4}-0.5, \mathrm{KH}_{2} \mathrm{PO}_{4}-0.5$, $\mathrm{MgSO}_{4} \cdot 7 \mathrm{H}_{2} \mathrm{O}-0.5, \mathrm{CaSO}_{4}-0.2$, pea -50 , agar -20 , water distilled - up to $1 \mathrm{~L}, \mathrm{pH}-6.8-7.0$ (pea was boiled during 1 hour and the medium was prepared on the basis of pea's broth).

\subsection{Treatment and Germination of Seeds}

Seeds of plants were treated with $96 \% \mathrm{H}_{2} \mathrm{SO}_{4}$ during $40 \mathrm{~min}$ for Ammodendron conollyi and $20 \mathrm{~min}$ for both Astragalus villossimus and Astragalus unifoliolatus, whereupon the seeds were repeatedly rinsed by sterile distilled water and transferred to $1 \%$ water agar with moisture enough for swelling of seeds and their germination in Petri dishes. Next 1-2 days after treatment with acid the seeds swelled and scarification of seed's coat was conducted, then opened appeared roots of seeds were submerged into sterile agar for fast development of seeds` roots in Petri dishes that were introduced into thermostat at $30^{\circ} \mathrm{C}$. After 2-3 days from the starting of seed germination the seedlings with developed roots were transplanted in potting substrate for their further development and growth.

\subsection{Preparation of Potting Substrate for Microvegetation/Vegetation Experiments}

The ability of desert leguminous plants seedlings to grow in ascending flow of nutritive solution in tubes (microvegetation experiments) was tested. Tubes were filled for one third volume by sterile nutritive solution and filter paper strips were introduced into the tubes, the upper end of which was fixed on the height $1-2 \mathrm{~cm}$ from the surface of nutritive solution in tubes, but the lower end of strips was submerged into the nutritive solution for formation of ascending flow of the nutritive solution. Composition of the nutritive solution for plant growing was following: $\mathrm{MgSO}_{4} \bullet 4 \mathrm{H}_{2} \mathrm{O}-5 \mathrm{mM}, \mathrm{K}_{2} \mathrm{SO}_{4}-10 \mathrm{mM}$, $\mathrm{CaCl}_{2} \cdot 2 \mathrm{H}_{2} \mathrm{O}-1 \mathrm{mM}$, phosphate buffer $\left(\mathrm{NaH}_{2} \mathrm{PO}_{4}+\right.$ $\mathrm{Na}_{2} \mathrm{HPO}_{4}$, pH 6.5) - $15 \mathrm{mM}$, microelements $-0.05 \mathrm{ml} / \mathrm{L}$ of medium, Fe source $-5 \mathrm{mM}$; microelements composition (g/L) $-\mathrm{H}_{3} \mathrm{BO}_{3}-17.16, \mathrm{MnSO}_{4}-7.2, \mathrm{ZnSO}_{4}-1.32$, $\mathrm{CuSO}_{4}-1.65, \mathrm{Na}_{2} \mathrm{MoO}_{4}-0.12$ [4]. The seedlings were put on the upper end of strips and inoculated by nodule bacteria.

As vessels for potting substrate 2-Litre volume black perforated bags (vegetation experiments) were used. 
They were filled by combinations of substrates (vermiculite, peat, sand, soil) that were sterilized at 1 atmosphere during $30 \mathrm{~min}$.

\subsection{Nodulation Test}

Ten strains of every nodule bacteria isolated from Ammodendron conollyi (AC1-1, AC2, AC4-1, AC8-1, AC11, AC12-1, AC13-1, AC15, AC18-1, AC21), Astragalus villossimus (AV1, AV2, AV3, AV6-1, AV8-1, AV9, AV9-1, AV26-1, AV30, AV36-1) and Astragalus unifoliolatus (AU2-1, AU3-1, AU4, AU7, AU17-1, AU20-1, AU23, AU28, AU30-1, AU30-2) were selected for inoculation. Strains of Azorhizobium caulinodans ORS571 (University of Nottingham, Centre for crop nitrogen fixation) and CXM1 (the Russian industrial strain for alfalfa inoculation) were also used. The bacteria were grown in $2 \%$ hard (agar-containing) medium with pea's broth during 3 days at $28^{\circ} \mathrm{C}$. The plant seedlings were sowed into bags on the depth of substrate $2-3 \mathrm{~cm}$ and further there was done an inoculation of planted seedlings with $5 \mathrm{ml}$ of culture nodule bacterial suspension $\left(10^{9}\right.$ cells $\left./ \mathrm{ml}\right)$ per each variant and simultaneous irrigation with nutritive solution.

\subsection{Determination of Nitrogen-Fixing Activity}

Nitrogen-fixing activity was estimated by the acetylene-reductase activity (ARA) assay described by Hardy [5]. The plant samples (with root nodules) were washed with sterile water and transferred into $60 \mathrm{ml}$ capacity tube fitted with airtight rubber stoppers. Acetylene (10 volume $\%)$ was injected and the tubes were incubated at $30^{\circ} \mathrm{C}$ for 24 hours. The data was the mean of three replicates. The samples without acetylene were used as control. The quantitative estimation of ethylene gas produced in the samples was measured on a gas chromatograph (Hewlett Packard-5890) using a "Porapak-N" column and a $\mathrm{H}_{2}$-flame ionization detector (FID). The acetylenereductase activity of the plants was expressed as ppm $\mathrm{C}_{2} \mathrm{H}_{4}$ tube/hour.

\subsection{Soil Moisture}

Soil moisture was measured with help of both TDR-method (electrical conductivity of soil) and gravimetric method (weighing of soil samples). The soil was taken from 0-30 cm horizons and was dried twice at $105^{\circ} \mathrm{C}$.

\subsection{Drying of Plant Biomass}

Drying of plant biomass for determination of biomass was conducted at $70^{\circ} \mathrm{C}$ during day.

\subsection{PCR Amplification of the $16 \mathrm{~S}$ rRNA Gene}

The 16S rRNA gene from nodule bacteria of Ammoden- dron conollyi (AC1-1, AC8-1, AC11, AC15, AC21), Astragalus villossimus (AV1, AV3, AV6-1, AV8-1, AV9) and Astragalus unifoliolatus (AU3-1, AU7, AU17-1, AU30-1, AU30-2) was amplified using universal primers 1070f (59-ACGGGCGGTGTG- TAC-39) and 1392r (59-CGCCCGCCGCGCCCCG- CGCCCGGCCCGCCGCCCCCGCCCC-ACGGGCGGTGTGTAC-39) [6]. Each PCR mixture contained the following: 10 pmol each primer, $200 \mu \mathrm{M}$ dNTPs, 1U Tag DNA polymerase, 100-200 ng genomic DNA and Taq polymerase buffer in a final reaction volume of $50 \mu \mathrm{l}$. The DNA thermal cycler used for PCR amplification was programmed as follows: an initial extensive denaturation step at $94^{\circ} \mathrm{C}$ for $5 \mathrm{~min}$; 30 cycles of $94^{\circ} \mathrm{C}$ for $1 \mathrm{~min}, 53^{\circ} \mathrm{C}$ for $1 \mathrm{~min}$ and $72^{\circ} \mathrm{C}$ for $1.5 \mathrm{~min}$; and a final extension step at $72^{\circ} \mathrm{C}$ for $10 \mathrm{~min}$.

\subsection{Phylogenetic Analysis}

The complete 302-343-bp 16S rRNA gene sequences were compared with the sequences available in the GenBank database using the standard Basic Local Alignment Search Tool, BLASTn [6], at the National Center for Biotechnology Information (NCBI) (http://blast. ncbi.nlm.nih.gov/Blast.cgi). From the aligned sequences, neighbor-joining dendrograms [8] were constructed with the software MEGA version 4.0.2 [9]. The robustness of the inferred trees was evaluated by 1000 bootstrap resamplings.

\subsection{Molecular-Genetic Investigations}

Symbiotic NIF- and NOD-genes were determined in nodule bacteria with help of correspondent probes Nif-probe (from Klebsiella pneumoniaea) and Nod-ABC probe (from Sinorhizobium fredii) - by means of dot-(Southern)-hybridization in nylon membranes [10].

Plasmids were visualized by the in-gel lysis method of Eckhardt [11] as modified by Priefer [12].

\subsection{Salinity Experiments}

Plants were irrigated by the nutritive medium containing $100 \mathrm{mM}, 200 \mathrm{mM}, 300 \mathrm{mM}$ and $500 \mathrm{mM} \mathrm{NaCl}$, with/without addition of $1 \mathrm{mM} \mathrm{NH} \mathrm{NO}_{3}$, up to saturation of potting substrate with the medium and its leaking from the bottom of perforated bags every $5^{\text {th }}$ day.

\subsection{Doubling Time of Bacterial Cells of Nodule Bacteria}

Nodule bacteria were grown in liquid TY medium at $30^{\circ}$ $\mathrm{C}$ in orbital shaker at $140 \mathrm{rpm} / \mathrm{min}$ and the increase of bacterial biomass was measured on optical density (photometrically). Obtained results were treated with special computer program supplied by Sevilla University. Composition of Ty medium was as followed $(\mathrm{g} / \mathrm{L})$ : bactotryptone -4 ; yeast extract $-2 ; \mathrm{CaCl}_{2} \cdot 6 \mathrm{H}_{2} \mathrm{O}-1.3$ or $\mathrm{CaCl}_{2} \cdot 2 \mathrm{H}_{2} \mathrm{O}-0.87$; phosphate buffer $\left(\mathrm{Na}_{2} \mathrm{HPO}_{4}-2.4\right.$; 
$\mathrm{KH}_{2} \mathrm{PO}_{4}-1.0$ ), $\mathrm{H}_{2} \mathrm{O}$ - up to $1 \mathrm{~L}, \mathrm{pH}$ - 6.8-7.0 [13].

\subsection{Light and Electron Microscopy}

Nodules of Ammodendron conollyi, Astragalus villossimus, Astragalus unifoliolatus were fixed in $2.5 \%$ glutaric aldehyde and $0.025 \mathrm{M}$ potassium phosphate $\mathrm{pH} 7.2$ during 4 hours at room temperature with further post-fixation in buffered 1\% osmium tetraoxide. Then nodules were dehydrated by acetone and in a series of alcohols with increased alcohol concentration and after this they were embedded into araldite. Mid-sections of nodules and ultra-thin sections were done in LKB-ultramicrotome (Sweden), they were contrasted with $1 \%$ uranyl-acetate and $0.8 \%$ led citrate prepared according Reynhold and were viewed in electron microscope "JEM (Jeol)-10” (Japan) at accelerating voltage 60-80 kilovolts.

For study of sections in the light microscope the sections were fixed in $2 \%$ osmium tetraoxide. After this they were coloured by mixture of equal parts of fuchsin and methylene blue in 1\% acetic acid. It should colour preparations during 3-5 seconds, otherwise they will be re-coloured and colour palette will change. In preparations nodule plant tissues are coloured in blue colour and bacteria - in red colour. Bacterial preparations were grown in TY hard medium (as mentioned above) during 18-20 hours. After growing up the bacterial cells 3-4 times were rinsed by $0.025 \mathrm{M}$ potassium phosphate buffer (pH 7.2) and centrifuged at 6,000 rpm during 20 min, and then they were fixed by $3 \%$ formalin solution (preliminarily neutralized by $\mathrm{K}_{2} \mathrm{CO}_{3}$ beforehand 24 hours). Before their transfer to special metallic grids the bacterial cells were fixed (contrasted) by $2 \%$ phosphorous-tungstic acid (pH 7.2) during 15 min and with help of sprinkler the cells were dusted to metallic grids. All electron microscopic samples were viewed in electron microscope "JEM (Jeol)-10" (Japan) in Central Asian Pediatric Institute (Tashkent, Uzbekistan).

\section{RESULTS}

\subsection{Isolation and Screening of Microbiological and Symbiotic Properties of Bacterial Isolates of Nodule Bacteria}

151 bacterial isolates of nodule bacteria were isolated from perennial leguminous plants of Kyzylkum Desert. During growth on hard pea's medium there were colourless, whitish, greyish, faintly-grey and yellowishreddish, transparent, semi-transparent and muddy with different degree of slime, convex, conical and spherical colonies, but rough colonies occurred also. They differed on growth rate - fast-growing bacteria prevailed and slowly-growing isolates occurred also. The time of col- ony appearance varied in average from 2 to 4 days (in slowly-growing ones - from 4-5 days and more). Bacterial isolates, isolated from Astragalus villossimus, were mainly represented by fast-growing bacteria, while bacterial isolates, isolated from from Ammodendron conollyi and Astragalus unifoliolatus, were represented by equal halves of both fast-growing bacteria and slowly-growing bacteria. During analysis of colonies and their slime production ability when their growing on the pea's agar it was noted that there was some correlation between appearance of colonies and their size; fast-growing bacterial isolates formed bigger colonies with middle slime production ability. The most of colonies, that had typical (characteristic features for nodule bacteria), they were greyish-white, semi-transparent, with abundant slime production. Bacterial colonies were mainly conical and they had convex profiles with even colony edges, that probably allows to suppose that they are S-forms of nodule bacteria. But, at the same time, there were also rough colonies, semi-transparent with uneven edges that perhaps can be considered like as R-формы [14]. After study of morphological-physiological properties and selection for growth rate (appearance of colonies in Petri dishes with medium for cultivation of bacteria) about 50 perspective isolates were selected. Analysis of cells growth of selected strains showed that fast-growing and moderately-growing strains occurred among them that had doubling time from 20 to $45 \mathrm{~min}$. The presence of salt in TY medium increased doubling time of strains by в 1.4-1.9 times in the presence of $0.75 \mathrm{M} \mathrm{NaCl}$ in comparison with control and by 1.6-4.0 times in the presence of $1 \mathrm{M} \mathrm{NaCl}$ (Table 1). At higher salt concentrations in medium composition the differences in salt-resistance became even more expressed: AV9-1 and AV30 strains lost an ability to grow, doubling time of AV3 and AV8-1 were by more than 26 times higher than control, while AV9 strain was less sensitive to salt and it had doubling time that exceeded control one only by 2 times. At salt content $1.75 \mathrm{M} \mathrm{NaCl}$ AU7 and AV3 strains lost a growth ability and in the rest of strains the increase of doubling time was observed. Finally, only AC11, AC15 and AV9 strains grew at $2 \mathrm{M} \mathrm{NaCl}$, where AV9 strain showed doubling time that exceeded control only by 3 times, but growth of C21 strain was extremely slow.

All strains were able to grow in the range of temperatures $12-40^{\circ} \mathrm{C}$, and AV9 strain - at $45^{\circ} \mathrm{C}$. Except for AV9 strain, all the rest strains grew in agar at $8^{\circ} \mathrm{C}$ (Table 2). During study of growth ability at different values of $\mathrm{pH}$ (from 4.0 to 11.0), many strains were able to grow except AV8-1 and AV9-1 strains that lost growth ability at $\mathrm{pH}$ 4.0. AC11 strain grew only starting from $\mathrm{pH}$ 6.0, and AU30-2 strain was able to grow only at $\mathrm{pH}$ values lower than 10.0 .

Testing of strains for resistance to antibiotics showed 
Table 1. Effect of salt on growth. Bacteria were cultivated in TY medium containing 0.04 (control), 0.75, 1.0, 1.5, 1.75 or $2.0 \mathrm{M}$ $\mathrm{NaCl}$. Cultures were maintained in an orbital shaker at $30^{\circ} \mathrm{C}$.

\begin{tabular}{|c|c|c|c|c|c|c|c|c|c|c|c|}
\hline \multirow{2}{*}{$\begin{array}{r}\text { Isolate } \\
\text { AC8-1 }^{(1)}\end{array}$} & \multirow{2}{*}{$\begin{array}{l}\begin{array}{c}\text { Control } \\
\mathrm{t}_{\mathrm{d}}(\mathrm{h})^{(\mathrm{a})}\end{array} \\
0.82\end{array}$} & \multicolumn{2}{|c|}{$\begin{array}{c}0.75 \mathrm{M} \\
\mathrm{t}_{\mathrm{d}}(\mathrm{h})\end{array}$} & \multicolumn{2}{|c|}{$\begin{array}{l}1.0 \mathrm{M} \\
\mathrm{t}_{\mathrm{d}}(\mathrm{h})\end{array}$} & \multicolumn{2}{|c|}{$\begin{array}{l}1.5 \mathrm{M} \\
\mathrm{t}_{\mathrm{d}}(\mathrm{h})\end{array}$} & \multicolumn{2}{|c|}{$\begin{array}{c}1.75 \mathrm{M} \\
\mathrm{t}_{\mathrm{d}}(\mathrm{h})\end{array}$} & \multicolumn{2}{|c|}{$\begin{array}{c}2.0 \mathrm{M} \\
\mathrm{t}_{\mathrm{d}}(\mathrm{h})\end{array}$} \\
\hline & & 129 & $(16)^{(b)}$ & 172 & (2) 1 ) & 427 & (5.2) & 1158 & (14 & $\mathrm{NG}^{(\mathrm{c})}$ & \\
\hline AC11 & $\begin{array}{l}0.02 \\
1.31\end{array}$ & $\begin{array}{l}1.23 \\
2.51\end{array}$ & (1.9) & $\begin{array}{l}1.12 \\
3.17\end{array}$ & $\begin{array}{l}(2.1) \\
(2.4)\end{array}$ & $\begin{array}{l}4.27 \\
10.33\end{array}$ & $\begin{array}{l}(5.2) \\
(7.9)\end{array}$ & $\begin{array}{l}11.58 \\
13.68\end{array}$ & (14.1) & 19.8 & (15.1) \\
\hline AC15 & 0.72 & 1.06 & (1.5) & 1.72 & (2.4) & 5.45 & (7.6) & 19.11 & (26.5) & 66.88 & (92.9) \\
\hline AC21 & 0.68 & 1.00 & (1.5) & 1.51 & (2.2) & 5.12 & (7.5) & 10.38 & (15.3) & NG & \\
\hline $\mathrm{AUU} 7^{(2)}$ & 0.84 & 1.29 & (1.5) & 2.01 & (2.4) & 15.57 & (18.5) & NG & & NG & \\
\hline AU17-1 & 0.84 & 1.46 & (1.7) & 2.08 & (2.5) & 8.85 & (10.5) & 33.44 & (39.8) & NG & \\
\hline AU30-1 & 0.77 & 1.08 & (1.4) & 2.52 & (3.3) & 11.92 & (15.5) & 42.13 & (54.7) & NG & \\
\hline AU30-2 & 1.08 & 1.66 & (1.5) & 2.6 & (2.4) & 12.04 & (11.1) & 45.60 & (42.2) & NG & \\
\hline $\mathrm{AV} 1^{(3)}$ & 0.81 & 1.31 & (1.6) & 1.75 & (2.2) & 7.46 & (9.2) & 24.27 & $(30.0)$ & NG & \\
\hline AV3 & 0.76 & 1.44 & (1.9) & 2.94 & (3.9) & 20.19 & (26.6) & NG & & NG & \\
\hline AV6-1 & 0.93 & 1.64 & (1.8) & 2.32 & (2.5) & 7.04 & (7.6) & 11.04 & (11.9) & NG & \\
\hline AV8-1 & 1.27 & 1.98 & (1.6) & 5.04 & $(4.0)$ & 37.62 & (29.6) & 150.48 & (118.5) & NG & \\
\hline AV9 & 0.75 & 1.13 & (1.5) & 1.20 & (1.6) & 1.50 & (2.0) & & & 2.26 & (3.0) \\
\hline AV9-1 & 0.84 & 1.44 & (1.7) & 3.16 & (3.8) & NG & & NG & & NC & \\
\hline AV30 & 0.81 & 1.29 & (1.6) & 2.12 & (2.6) & NG & & NG & & $\begin{array}{l}\mathrm{NG} \\
\mathrm{NG}\end{array}$ & \\
\hline
\end{tabular}

(a) Doubling time; ${ }^{(\text {b) }} \mathrm{t}_{\mathrm{d}}$ : $\mathrm{t}_{\mathrm{d}}$ of control; ${ }^{(\mathrm{c})}$ No detectable growth.

$\mathrm{AC}^{(1)}$ - nodule bacteria isolated from Ammodendron connollyi nodules;

$\mathrm{AU}^{(2)}$ - nodule bacteria isolated from Astragalus unifoliolatus nodules;

$\mathrm{AV}^{(3)}$ - nodule bacteria isolated from Astragalus villossimus nodules.

Table 2. Relevant characteristics of the isolates described in previous.

\begin{tabular}{|c|c|c|c|c|c|c|c|c|}
\hline Isolate & $\begin{array}{l}\mathrm{t}_{\mathrm{d}}^{(\mathrm{a})} \\
\text { (h) }\end{array}$ & $\begin{array}{l}\mathrm{NaCl} \\
\operatorname{limit}^{(b)} \\
(\mathrm{M})\end{array}$ & $\begin{array}{l}\text { Plasmid } \\
\text { (kbp) }\end{array}$ & $\begin{array}{l}\text { Antibiotic } \\
\text { Resistance }\end{array}$ & $\begin{array}{l}\text { Growth } \\
\text { temp., }{ }^{\circ} \mathrm{C}\end{array}$ & $\begin{array}{l}\text { Growth } \\
\mathrm{pH}\end{array}$ & $\begin{array}{l}\text { Melanin pro- } \\
\text { duction }\end{array}$ & $\begin{array}{l}\text { Colony } \\
\text { Type }\end{array}$ \\
\hline AC8-1 & 0.82 & 1.75 & 370,515 & Amp & $8-40$ & $4-11$ & - & I \\
\hline AC11 & 1.31 & 2.00 & 370,515 & $\mathrm{Cm}$ & $8-40$ & $6-10$ & weak & II \\
\hline AC15 & 0.72 & 2.00 & $118,370,515$ & Amp & $8-40$ & $4-11$ & - & $\mathrm{I}$ \\
\hline AC21 & 0.68 & 1.75 & 370,515 & Amp & $8-40$ & $4-11$ & - & I \\
\hline AU7 & 0.84 & 1.50 & 370,515 & Amp, Km, Str, Tc & $8-40$ & $4-11$ & + & I \\
\hline AU17-1 & 0.84 & 1.75 & 370,515 & Amp, Tc & $8-40$ & $4-11$ & + & I \\
\hline AU30-1 & 0.77 & 1.75 & 370,515 & Amp, Km, Str, Tc & $8-40$ & $4-11$ & +++ & III \\
\hline AU30-2 & 1.08 & 1.75 & 370,515 & Amp, Tc & $8-40$ & $4-10$ & + & IV \\
\hline AV1 & 0.81 & 1.75 & $118,370,515$ & Amp, Tc & $8-40$ & $4-11$ & + & I \\
\hline AV3 & 0.76 & 1.50 & $118,370,515$ & & $8-40$ & $4-11$ & - & II \\
\hline AV6-1 & 0.93 & 1.75 & 370,515 & Amp, Tc & $8-40$ & $4-11$ & + & I \\
\hline AV8-1 & 1.27 & 1.75 & $118,370,515$ & Amp, Cm & $8-40$ & $5-11$ & - & I \\
\hline AV9 & 0.75 & 2.00 & $118,370,515$ & & $12-40$ & $4-11$ & - & V \\
\hline AV9-1 & 0.84 & 1.00 & $118,370,515$ & & $8-40$ & $5-11$ & - & IV \\
\hline AV30 & 0.81 & 1.00 & 370,515 & Amp, Cm, Km, Str & $8-40$ & $4-11$ & ++ & VI \\
\hline
\end{tabular}

(a) Doubling time in TY liquid medium at $30^{\circ} \mathrm{C}$.

(b) Highest concentration of $\mathrm{NaCl}$ in $\mathrm{TY}$ liquid medium at which growth was observed (see Table 1).

that amount of colonies decreased somewhat in the presence of chloramphenicol (and in some cases in the presence of other antibiotics), but in all strains the resistance to antibiotics was observed. The ability to grow in dishes with ampicillin was the most widespread in all strains, it was followed further with ability to grow in the presence of tetracycline. AU7 and AU30-1 strains grew in the presence of four of the antibiotics (ampicillin, kanamycin, streptomycin, tetracycline, Table 2).
During identification of Nod- and Nif-genes in selected bacterial isolates with help of dot-hybridization and specific probes the positive hybridization reflexes were obtained. In this study of selected bacterial isolates for salt-resistance about 30 perspective strains of nodule bacteria were revealed which were able to grow in the presence of $1 \mathrm{M} \mathrm{NaCl}$ and more (up to $2 \mathrm{M} \mathrm{NaCl}$ ). During study of plasmid profile of strains from 2 (in nodule bacteria strains of Ammodendron conollyi and Astraga- 
lus unifoliolatus) to 3 megaplasmids (in Astragalus villossimus nodule bacteria strains) with molecular masses 118, 370 and $515 \mathrm{kB}$ correspondingly (Table 2).

Melanin formation is a phenotypic feature which can also help in identification of closely-related rhizobia. Screening of isolates on this feature was conducted in a way of detection of diffusing dark-brown pigment that is produced with cells grown in Petri dishes containing TY medium with added tyrosine and copper [15]. The fast and abundant formation of melanin was observed in U30-1 strain and almost the same like it took place in V30 strain; lesser formation of melanin was observed in AU7, AU17-1, AU30-2, AV1 and AV6-1 strains. The rest of strains did not produce diffusing dark pigment and they were considered like as Mel-strains (Table 2).

All strains grew in Luria-Bertani medium [12]. Testing of their growth in TY medium showed at least 6 different types of colonies:

Type 1: Middle size, round, convex, light and white.

Type 2: Young colonies like as in type 1, they become yellow later.

Type 3: Young colonies like as in type 1, they become yellow-brown later.

Type 4: As type 1, but smaller in sizes.

Type 5: Middle size, round, dim and curly.

Type 6: Young colonies like as in type 1, later they become darker than type 3 .

All above-mentioned investigations have confirmed that the selected isolates are nitrogen-fixing nodule bacteria which are able in the wide ranges of $\mathrm{pH}$ and temperatures.

\subsection{Germination of Plant Seeds, Nodulation Test (Direct Inoculation and Cross-Inoculation)}

After study of microbiological properties of bacterial isolates of nodule bacteria next stage of investigations was a study of their symbiotic properties. It was necessary for this to conduct a search of optimal conditions for seed germination of wild desert leguminous plants (Ammodendron conollyi tree, Astragalus unifoliolatus and Astragalus villossimus shrubs), their growth and development as well as nodulation process of these plants roots upon inoculation with selected isolates (strains) of nodule bacteria.

No prolonged treatment of plant seeds with concentrated sulphuric acid (Ammomodendron conollyi during 3 hours) nor their moistening in water during several days did not lead to increase of seed germination output of desert xerophyte plants higher than $10-15 \%$ (in natural conditions $5-10 \%$ output of seed germination is observed) [16]. In literature there are data about efficiency of scarification of only hygrophilous foot-hill species of acacia [17].

As a result of search the combination of treatment with sulphuric acid and scarification of root part of seeds was found when almost total (about 90-95\%) seed germination of xerophyte desert wild leguminous plants in sterile conditions was obtained. The tasks of investigations included growing up of seedlings up to mature state and study of root nodulation of the grown up plants.

First of all it was necessary to obtain normal vegetation of plants (that would be favourable for their nodulation). During study of nodulation it was important to clear up two matters:

1) to determine the belonging (biological test) of isolated nodule bacteria to their maternal host-plants and, thus, to confirm their originality (“direct inoculation”);

2) to examine a host specificity of nodule bacteria towards other (non-maternal) host plants ("cross-inoculation”).

During search of optimal conditions for plants growing up the following types of potting substrates were used:

1) Microvegetation experiments:

Strips of filter paper in agronomic tubes $(60 \mathrm{ml})$ with ascending flow of nutritive solution for plants in sterile conditions.

Vegetation experiments:

2) Sterile vermiculite impregnated with nutritive solution for plants in pots $(0.7 \mathrm{~L})$ in greenhouse.

3) "Light structure" in bags (sterile, 2 L) - 1 part peat: 1 part vermiculite: 1 part soil: 2 parts sand.

4) "Structure close to natural conditions" (in bags) - 3 parts sand: 1 part vermiculite.

5) Natural conditions (fine-grained sand).

6) Field conditions (soil).

In microvegetation experiments during growing and inoculation of plants seedlings with nodule bacteria on filter paper strips after 1 month both suppression and stoppage of their growth and development were observed. In vegetation experiments at growing on the $2^{\text {nd }}$ type of substrate the height of plants was good, but after 45 days from the starting of experiment the stoppage of growth and development was observed also. In both previous experiments there was no nodulation. Probably, plants being xerophytes and in natural conditions having only low moisture in the upper soil horizon $(0-30 \mathrm{~cm})$, they did not "manage" with moisture excess in two previous variants, because the presence of available moisture exceeded the transpiration of water by desert plants. In this connection it was necessary to create the conditions close to natural conditions. To achieve this aim the $3^{\text {rd }}$ type with sand prevalence was taken together with "light" potting structures (vermiculite would retain more moisture) which would accelerate drainage and removal of water from potting substrate, during this the moisture was supported within range 15-20\%. After 2.5 months (from moment of seedling planting up to the mature state) of growing in the $3^{\text {rd }}$ type the height and development of plants corresponded to 1-2 yearly plants $(15-30 \mathrm{~cm})$ that were observed in nature. But, there was not nodulation 
(there were only single nodules). During use of the $4^{\text {th }}$ type of substrate, where sand was dominating part of substrate and conditions were close to natural ones, the intense growth and development of plants was observed. After 2 months of growing the nodulation was found in all plants, and thus, the search of optimal conditions for total nodulation finally has crowned with success. But, nodulation after inoculation with Azorhizobium caulinodans ORS571 and CXM1 was not observed. Further, all experiments on study of plant nodulation were conducted in sand, the $5^{\text {th }}$ type of potting substrate.

As it is seen from Figure 1(a) and Table $\mathbf{3}$ the nodules of Ammodendron conollyi, formed after inoculation, were pink and large (up to $7 \mathrm{~mm}$ in diameter). In variants of Ammodendron conollyi plant inoculation the average nodule number per plant was $1-5$ and their biomass comprised 4.5-27.5 mg. At the same time the nitrogen fixation intensity did not influence essentially on the height of shoot part and length of roots. High nitrogen-fixing activity was recorded in direct inoculation with own nodule bacteria, isolated from Ammodendron conollyi (AC1-1, AC2, AC12-1, AC18-1, AC21). The cross-inoculation of Ammodendron conollyi plants by nodule bacteria isolated from Astragalus villossimus, has led to visibly low nitrogen-fixing activity in comparison with results of direct inoculation of the same plants with own nodule bacteria. It should be noted that crossinoculation of Astragalus villossimus plants by Ammodendron conollyi nodule bacteria (AC8-1, AC11, AC15) gave comparatively higher values of nitrogen fixation than their direct inoculation with own Astragalus villossimus nodule bacteria, during this there was an increase of nodules amount in Astragalus villossimus plants. As it is seen from Table 3, AC1-1 strain was more specific towards maternal Ammodendron conollyi plants during direct inoculation than Astragalus villossimus plants during their cross-inoculation. It is interesting to note that, on the whole, nitrogen-fixing activities of Ammodendron conollyi plants inoculated with direct inoculation and cross-inoculation were in several times higher than nitrogen-fixing activities of inoculated Astragalus villossimus plants and Astragalus unifoliolatus plants. Highly-efficient symbiosis (under term "symbiosis efficiency" is meant the increase of biomass of inoculated plants in comparison with biomass of non-inoculated plants) in Ammodendron conollyi plants was observed during inoculation with such nodule bacteria as AC1-1, AC8-1, AC11, AC12-1, AC18-1, AV1, AV8-1, AV9-1, AV30, when efficiency (biomass) of shoot part increased from 143.2 to $168.6 \%$ in comparison with control. At observation of Astragalus villossimus plants (Table 3) during direct inoculation with AV1, AV2, AV3, AV9, AV26-1 and cross-inoculation by AC11, AC15, AC21 and AU30-1 numerous nodules were formed (average nodule number $10-29$ and $1-2.5 \mathrm{~mm}$ size, their colour varied from weakly-reddish to white and greenish) (Figure 1(b)). High nitrogen-fixing activity of symbiosis of inoculated Astragalus villossimus plants was observed during direct inoculation with their own nodule bacteria AV2, AV3, AV9, AV30 and AV36-1. At the same time during cross-inoculation of Astragalus villossimus plants with Astragalus unifoliolatus nodule bacteria the comparatively low nitrogen-fixing activity was obtained than during direct inoculation. Efficiency from 121.5 to 128.4\% was obtained during inoculation with AV1, AV3, AV8-1, AV9 and AC8-1 strains.

During inoculation of Astragalus unifoliolatus plants the highest nodule number - up to 41 - was recorded, nodules were numerous and small (0.5-1.5 mm) (Figure 1(c)). Astragalus unifoliolatus plants, inoculated with their own nodule bacteria (direct inoculation) had considerably low nitrogen fixation than under cross-inoculation by nodule bacteria of Astragalus villossimus. High efficiency of Astragalus unifoliolatus symbiosis was observed at direct inoculation with AU23, AU28, AU30-1 and cross-inoculation by AV1, AV2, AV6-1, AV8-1 and AV9-1 strains.

\subsection{Phylogenetic Analysis of the 16S rRNA Gene of Nodule Bacteria Strains}

For taxonomic identification and creation of phylogenetic tree 15 salt-tolerant bacteria were re-isolated again from nodules formed on the roots of desert leguminous plants which were grown in sterile vegetation experiment. Results of BLAST-analysis for sequence of $16 \mathrm{~S}$ rRNA gene of bacteria showed that studied bacteria were related to Alphaproteobacteria and Betaproteobacteria classes. The nucleotide sequence of 16S rRNA gene of AC1-1, AC8-1, AC21, AV1, AV3, AU3-1, AV8-1, AV9 and AU30-1 strains matched by $96-97 \%$ together with analogous genes of Rhizobium sp. GGNM 66; the genes of AC15, AU17-1, AU30-2 and AU7 bacteria were identical by $89-97 \%$ to nucleotide sequences of Burkholderia cepacia NBRAJG97 species and the genes of AC11 and AV6-1 strains were identical by $95 \%$ and $98 \%$ to genes of Achromobacter xylosoxidans species. On phylogenetic tree the studied bacteria could be grouped into 4 clusters (Figure 2): AU7 strain (Astragalus unifoliolatus) formed the $1^{\text {st }}$ cluster, the $2^{\text {nd }}$ cluster included AC11 (Ammodendron conollyi) and AV6-1 (Astragalus villossimus) strains, the $3^{\text {rd }}$ group was created by AC15 (Ammodendron conollyi), AU17-1 and AU30-2 (Astragalus unifoliolatus) strains, and, at last, the $4^{\text {th }}$ big group was formed by AC1-1, AC8-1, AC21 (Ammodendron conollyi); AV1, AV3, AV8-1, AV9 (Astragalus villossimus), Astragalus unifoliolatus (AU3-1; AU30-1) nodule bacteria strains. It may conclude from obtained results that nucleotide sequences of $16 \mathrm{~S}$ rRNA gene of studied bacteria that were highly identical between themselves within group and also bacteria isolated from each cor- 


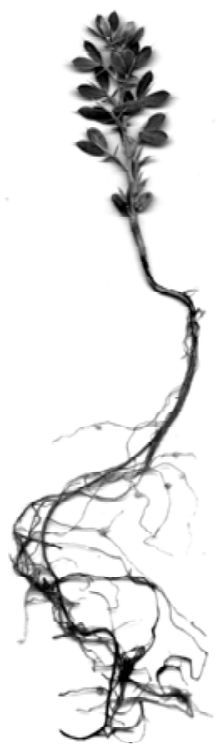

(a)

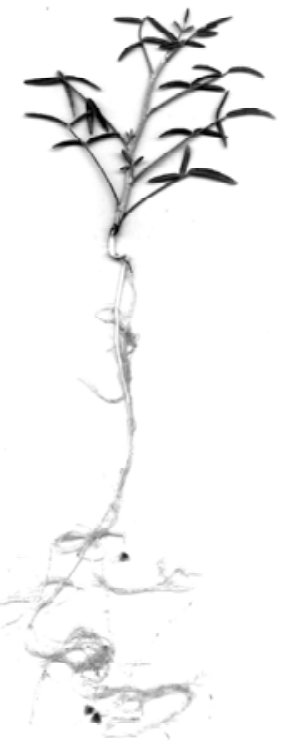

(b)

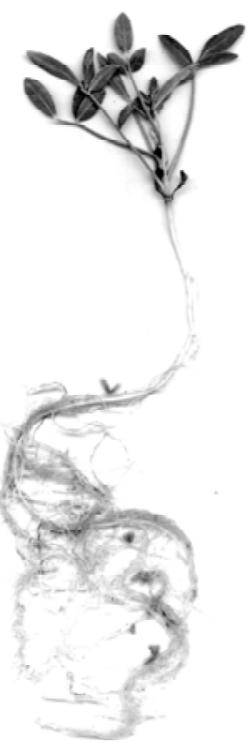

(c)

Figure 1. Nodulation of desert leguminous perennial plants: (a) Inoculation of Ammodendron conollyi plant with AC11 strain; (b) Inoculation of Astragalus villossimus plant with AV8-1 strain; (c) Inoculation of Astragalus unifoliolatus plant with AU30-2 strain.
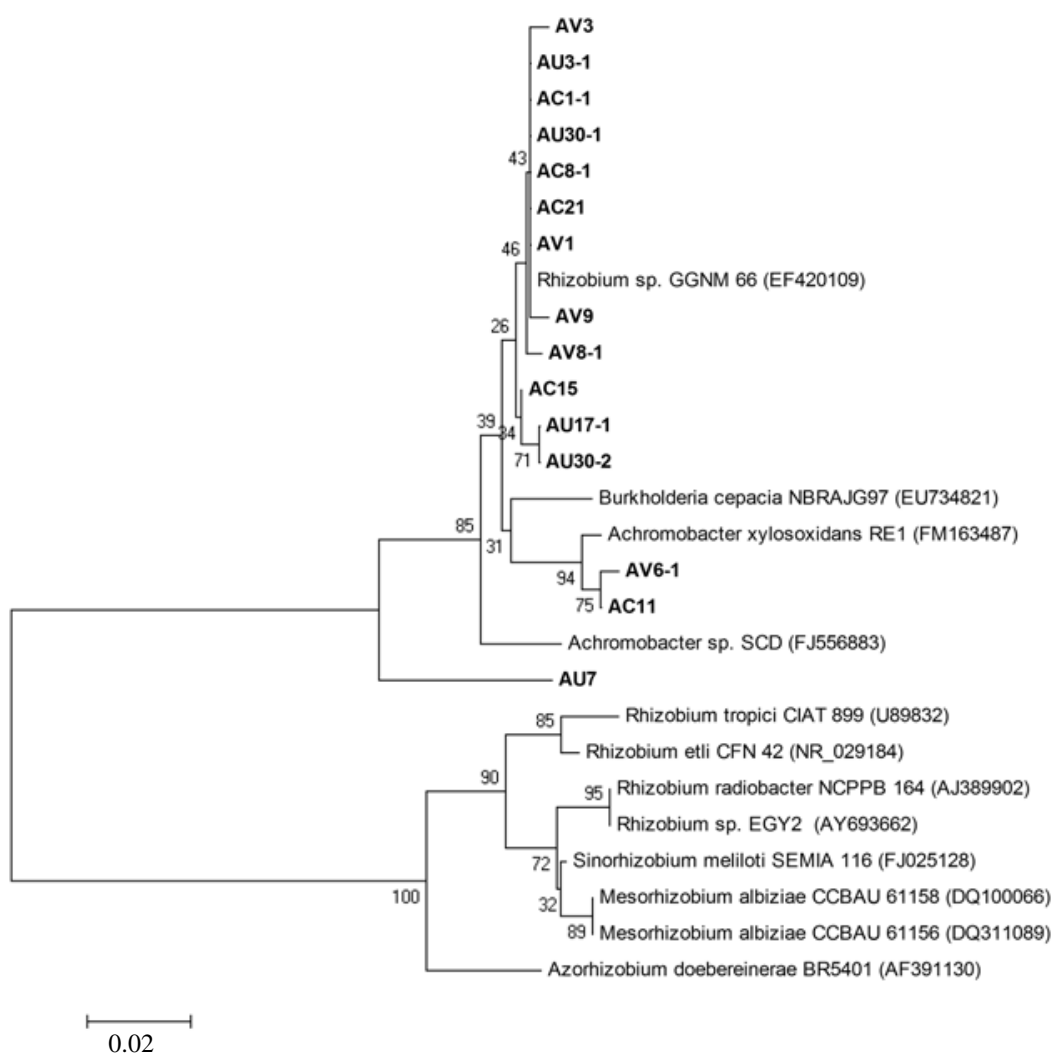

Figure 2. Phylogenetic tree based on the 16S rRNA gene strains of nodule bacteria from desert leguminous perennial plants. The branching pattern was produced by the neighbour-joining method. The GenBank accession numbers for the sequences used are indicated in parentheses. Symbionts of desert legume plants are shown in bold type. 
respondent leguminous host plant were related to both Alpha class and Betaproteobacteria class.

\subsection{Study of Influence of Drought and Salinity on Symbiosis of Desert Leguminous Plants}

Experiment on study of influence of drought on xerophyte desert leguminous plants was carried out in greenhouse in soil (field conditions, the $6^{\text {th }}$ type) during 2.5 months. Plants, inoculated by correspondent nodule bacteria (AC21-1, AV1, AU30-1), were planted in rows into the soil and the first irrigation was done to equalize of soil moisture under the plants and one week later the soil moisture was within range 15-20\%. Afterwards the further irrigation of soil (the area which did not include the square which was not occupied by plants) was done from one side across the rows of planted plants. For whole period of plants growing there were 3 (three) such irrigations in order to obtain a gradient of soil moisture.

The gradient of soil moisture was obtained due to that irrigation was conducted from the one side (side of the first plants from each row), but on the contrary side of the last plants (according to order of row) there were constantly dried dehydrated soils. As a result the gradient of soil moisture in the range from 4 to $7 \%$ was obtained. During growing of plants the gradient of plants height - from the side of conducted irrigation (the beginning of row) to the contrary side (end of row) - was obtained. Thus, model system for study of plants drought resistance was created. From Figure $\mathbf{3}$ it is seen that from the moment of starting of experiment up to plants harvesting the gradient of soil moisture comprised from 3.8 to $6.41 \%$. The height and biomass of inoculated plants also decreased during this. Maximal height and biomass of inoculated plants of Ammodendron conollyi were $21 \mathrm{~cm}$ and $2320 \mathrm{mg}$ (at $6.41 \%$ soil moisture), but at
3.8\% moisture the height decreased by 4 times (up to $4.5 \mathrm{~cm}$ ) and biomass - by 11 times (203 mg). Analogous situation was observed in Astragalus unifoliolatus. For mation of nodules in this experiment was not observed. As our experiments showed, even under insignificant increase of soil moisture from 3.8 to $4.32 \%$ (by $0.52 \%$ ), the biomass of all studied plants increased by $2-3$ times, and under further increase from 3.8 to $6.41 \%$ (by $2.61 \%$ ) the biomass of all plants increased by $10-15$ times. At the same time it should be noted that under increase of moisture from 5.48 to $6.41 \%$ (by $0.93 \%$ ) the biomass of all plants increased only by 1.5 times. From here one may conclude that $6.41 \%$ of soil moisture for these plants is emergent value which is close to stationary level of moisture that is optimal for growth and development of these plants (Figure 3). Analogous results were received for plants Astragalus villossimus as well.

For conducting of experiment on salinity 20-daily saplings of these plants were taken, that further were subjected to salt stress under their irrigation with nutritive medium for plants that contained 100 mM, 200 mM, 300 $\mathrm{mM}$ and $500 \mathrm{mM} \mathrm{NaCl}$ for each irrigation. Experiment was conducted in two modifications: a) without added nitrogen, and b) on the background of added nitrogen (1 $\mathrm{mM} \mathrm{NH} \mathrm{NO}_{3}$ ). Plant inoculation was done with the correspondent nodule bacteria during seedling plantings into the bags: Ammodendron conollyi - by AC8-1 strain, Astragalus villossimus - by AV9 strain and Astragalus unifoliolatus - by AU30-1 strain. As it is seen from Figure 4, under salinity treatments with 100 and $200 \mathrm{mM}$ $\mathrm{NaCl}$ both in the absence and in the presence of added nitrogen ( $1 \mathrm{mM} \mathrm{NH}_{4} \mathrm{NO}_{3}$ ) as a sole nitrogen source, the survival of Ammodendron conollyi inoculated plants remained almost entirely - 75-100\%, and average green biomass of 1 plant increased by $16.2 \%$ in comparison with control. Further increase of $\mathrm{NaCl}$ concentration up

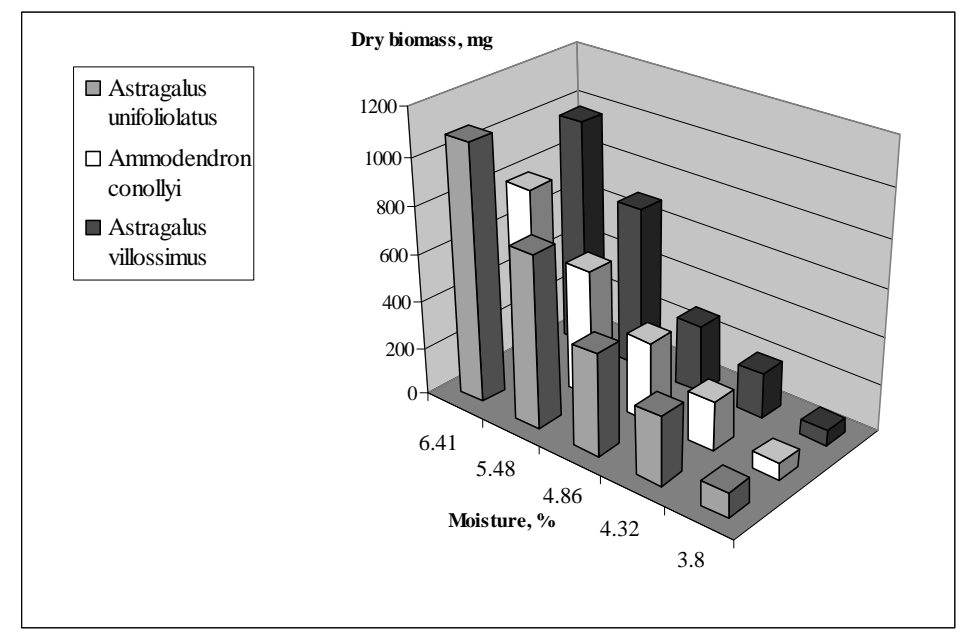

Figure 3. The influence of drought on dry biomass of perennial desert leguminous plants. 
to $500 \mathrm{mM}$ negatively influenced on yieldness and survival of Ammodendron conollyi plants under both presence and in the absence of nitrogen source, the survival decreased up to 25 and 50\% accordingly (Figure 4).

Study of salinity influence on Astragalus species showed that at $100 \mathrm{mM} \mathrm{NaCl}$ the survival of Astragalus villossimus was 46.1\% and for Astragalus unifoliolatus $66.7 \%$. It is interesting to note that in spite to decrease of survival of Astragalus villossimus in the presence 100 $\mathrm{mM} \mathrm{NaCl}$, the average green biomass (yieldness) of one plant increased by $40 \%$ in comparison with control, and at $300 \mathrm{mM} \mathrm{NaCl}$ the yieldness got equalized with control. At salinity from 100 to $500 \mathrm{mM} \mathrm{NaCl}$ both in the absence and in the presence of nitrogen the survival of Astragalus villossimus and Astragalus unifoliolatus regularly decreased. Nodulation was observed in Ammodendron conollyi in amount 1-2 nodules /1 plant at $100 \mathrm{mM} \mathrm{NaCl}$, while in Astragalus villossimus (11.0 0.25 nodules/ plant) - up to $200 \mathrm{mM} \mathrm{NaCl}$ and for Astragalus unifoliolatus (12.5 - 1 nodules/1 plant) - up to $300 \mathrm{mM} \mathrm{NaCl}$.

Individual plants of Ammodendron conollyi and Astragalus unifoliolatus were resistant to $100-200 \mathrm{mM}$ $\mathrm{NaCl}$, these salinity values did not influence practically on normal growth and development, while in Astragalus villossimus such concentration of salt-resistance was up to $100 \mathrm{mM} \mathrm{NaCl}$. This testified about individual adaptation of studied plants subjected to salt stress. Further study of influence of $\mathrm{NaCl}$ on growth and development of Ammodendron conollyi, Astragalus villossimus and Astragalus unifolilatus showed that salinity up to $500 \mathrm{mM}$ considerably decreased yieldness and survival of plants, but it also indicated to the fact that the last concentration of $\mathrm{NaCl}$ was not critical value for salt-resistance of studied plants.

\subsection{Light/Electron Microscopy of Nodule Bacteria and Transections of Nodules}

During electron-microscopic study of typical samples of

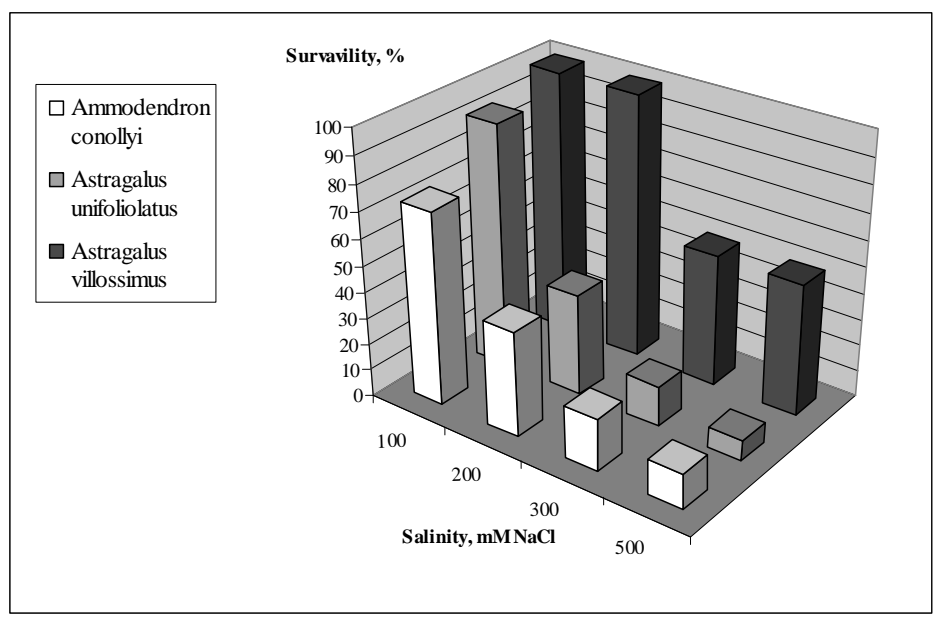

Figure 4. The influence of salinity on survival of perennial desert leguminous plants (in the presence of nitrogen source).

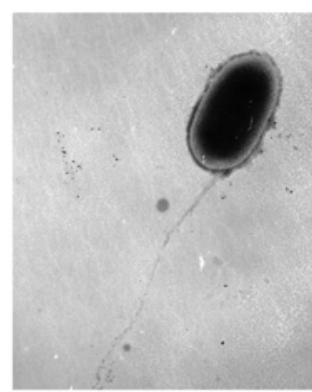

$0.17 \mathrm{mkm}$

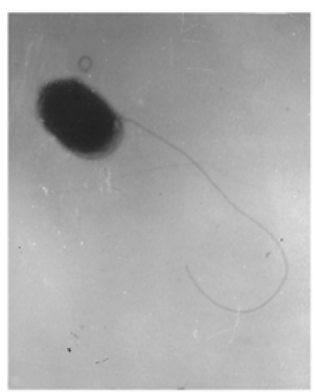

$0.17 \mathrm{mkm}$

(a)

(b)

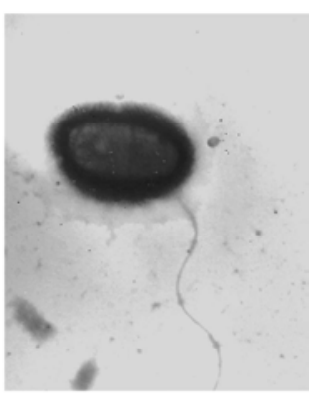

$0.2 \mathrm{mkm}$

(c)

Figure 5. The desert nodule bacteria in free-living state: (a) - Astragalus villossimus's nodule bacterium AV1 strain (magnification 5,000); (b) Ammodendron conollyi's nodule bacterium AC8-1 strain (magnification 5,000); (c) - Astragalus unifoliolatus's nodule bacterium AU30-1 strain (magnification 6,000). 
selected samples of nodule bacteria the unipolar monotrichous mobile rod-shaped forms of bacterial cells were revealed (Figure 5). Under differential colouring of nodule transections (preparations of light microscopy) of desert leguminous plant - Ammodendron conollyi tree or “sandy acacia”, Astragalus villossimus and Astragalus unifoliolatus shrubs it was possible to observe the similarity in organization and development of specific cellular structures, and also some difference between them. So, for example, under inoculation of Astragalus villossimus plants with AV1 strain it took place a wide and intensive colonization of internal plant cells of nodule (located to the nodule's center) by bacterial cells of this strain. As it is shown in Figure 6, after branchy (coloured in pink colour) bacterial net in outer covering cells of nodule the zone of formation and development of centres of infection threads followed further which finally (at least) led to formation of completely colonized (densely-colonized) deep internal plant cells of Astragalus villossimus nodule by bacterial cells of nodule bacteria.

Under higher amplifications it was possible to see a formation of "stairs-like" structures that seemingly are intracellular infection threads from which nodule bacteria further released into plant nodule cells and are transformed into non-mobile symbiotic forms - "bacteroids" within plant cells. It is important to note that infection threads move through and develop along perimeter of plant cells, i.e. along membranes of internal cells of plant nodule cells $[18,19]$. The microscopy results concerning to influence of salinity effect on the formed symbiosis showed that number of nodule bacteria cells internallycolonizing plant nodule decreased already at $100 \mathrm{mM}$ $\mathrm{NaCl}$ in comparison with control (Figure 6(g)), and under the further increase of $\mathrm{NaCl}$ salinity concentration up to $200 \mathrm{mM}$ the nodule bacteria colonization of nodule internal spaces reduced practically (Figure 6(h)).

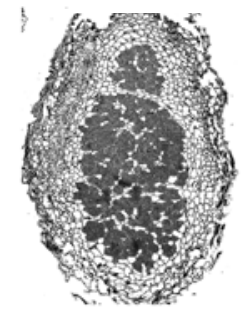

$100 \mathrm{mkm}$

(a)

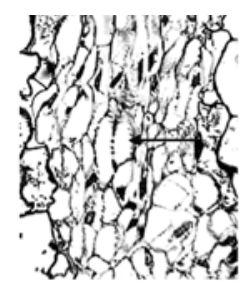

$10 \mathrm{mkm}$

(e)

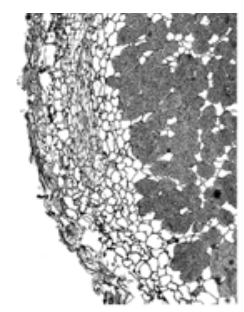

$50 \mathrm{mkm}$ (b)

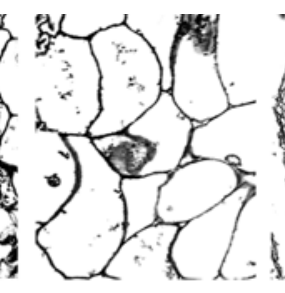

$5 \mathrm{mkm}$

(f)

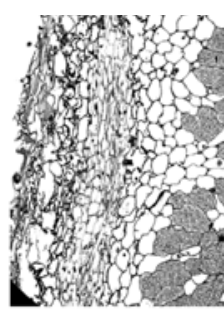

$30 \mathrm{mkm}$

(c)

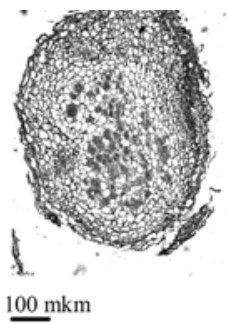

(g)

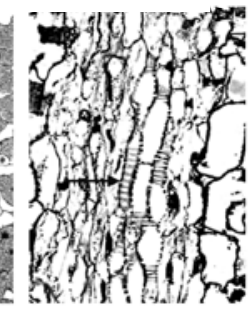

$10 \mathrm{mkm}$

(d)

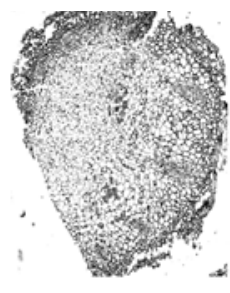

$100 \mathrm{mkm}$

(h)

Figure 6. Light microscopy of nodule transection of Astragalus villossimus plant, inoculated with its own Astragalus villossimus AV1 nodule bacteria strain: (a) - General picture of longitudinal part of nodule (magnification 148); (b) - Part of general picture taken under higher magnification (magnification x 315); not only central plant cells of nodule densely-colonized by bacterial cells, but also outer covering plant cells of nodule are visible, the zone of formation and development of infection threads centres follows further; (c) - Higher magnification of the same part (magnification 530); the outer bacterial net on plant bark (cortical) part is visible; (d) and (e) Higher magnification of the infection thread zone (magnification 974); "stairs-like" intracellular infection threads are visible (they are shown by arrows) and perhaps some elements of inter-cellular infection threads (spherical-like black-red structures) ; (f) - The highest magnification (magnification 2835); development and distribution of thick infection threads along plant membranes of nodule and through nodule cells with releasing bacterial cells of nodule bacteria; (g)-(h) - The light microscopy of Astragalus villossimus nodule section of plant grown at salinity $100 \mathrm{mM} \mathrm{NaCl}$ (g) and $200 \mathrm{mM} \mathrm{NaCl}$ (h). 
For study and observations of more fine structural properties of legume-rhizobial symbiosis of desert leguminous plants and selected nodule bacteria the electron-microscopic preparations were used. In the whole, bacteroids were represented by polymorphic structural forms - from globular (spherical) up to mace-like and many other random-shaped forms (Figures 7(a)-(c)). As to infection threads, the use of electron microscopy enabled to observe them more in detail. Infection threads formed in both inter-cellular free spaces between plant nodule cells (Figures 7(d) and (e)) and within plant nodule cells (Figures 7(f)-(i)). The form of infection threads also varied - from roundish to rectangular (Figures 7(d)-(i)).
Thus, as a result of legume-rhizobial symbiosis the structural reconstructions of both nodule bacteria and legume host plant took place (occurred). Under this not only penetration of bacteria into plant nodule cells and their colonization by bacteria occurs, but also transformation (transition) of free-living uniform mobile cells of nodule bacteria into symbiotic polymorphic non-motile forms (bacteroids). Penetration of nodule bacteria into correspondent host plant is realized through special structure - infection thread - that moves forward and distribution of which occurs through inter-cellular free spaces between plant nodule cells within their volumes [20,21].

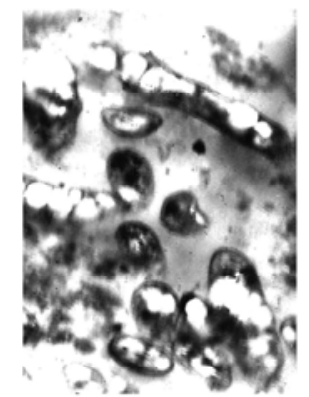

$0.7 \mathrm{mkm}$

(a)

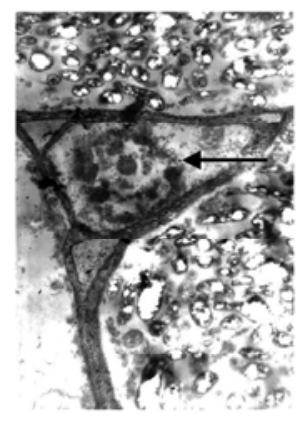

$2 \mathrm{mkm}$

(d)

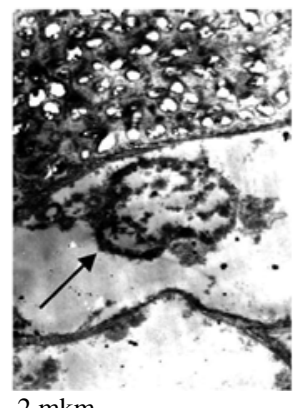

$2 \mathrm{mkm}$

(g)

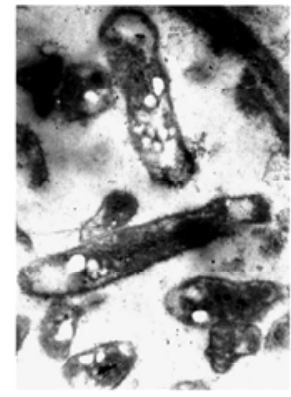

$0.5 \mathrm{mkm}$

(b)

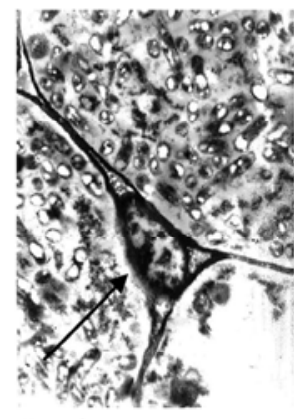

$2 \mathrm{mkm}$

(e)

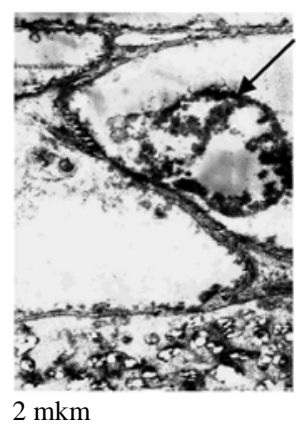

(h)

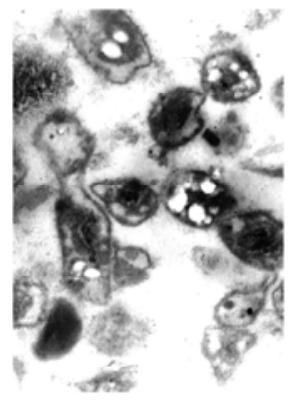

$0.5 \mathrm{mkm}$

(c)

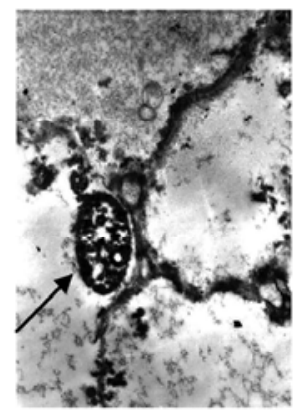

$2.5 \mathrm{mkm}$

(f)

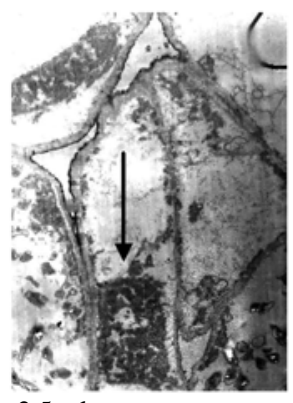

$2.5 \mathrm{mkm}$

(i)

Figure 7. Electron microscopy of nodules sections for desert legume plant Ammodendron conollyi: (a) (AV1), (b) (AC8-1) and (c) (AU30-1) - polymorphism of bacteroids, (d) (AV1) and (e) (AC8-1) - intercellular infection threads, (f)-(i) - intracellular infection threads. Localization of infection threads is indicated by arrows. 


\section{DISCUSSION}

From obtained results one can conclude that there was correlation between nitrogen-fixing activity and efficiency of symbiosis by nodule bacteria AC1-1, AC12-1, AC18-1, AC8-1, AV1, AV3, AV9, AU23 and AU30-1. On the basis of this data one can estimate the specificity of nodule bacteria towards leguminous host plant. During this it is necessary to consider both direct host nodulation specificity (belonging of nodule bacterium to definite maternal host plant from which this bacterium originates from) and wide host/cross host nodulation specificity (ability of this bacterium to form nitrogen-fixing symbiosis with other non-maternal host plants). So, under analysis of nitrogen-fixing activity and nodulation in Table $\mathbf{3}$ one can note that nodule bacteria of Ammodendron conollyi have the highest host specificity towards both their own maternal host plant and also to other host plants (wide host specificity), and in this connection they are the most perspective inoculants for obtaining of efficient symbiosis in perennial desert plants. Nodule bacteria of Astragalus villossimus have the middle specificities towards to its maternal host plant and other plants. Nodule bacteria of Astragalus unifoliolatus have lower specificity towards own maternal host plant and other plants. Thus, one can suppose that there is some regularity between attaching of nodule bacteria to concrete habitat and their specificity to come into symbiosis with different host plants. Since the collection of nodules of Ammodendron conollyi (they were sampled from Kara-Kata, Kyzylkum Desert), Astragalus villossimus (they were taken from Kyzylkum Desert Biostation) and Astragalus unifoliolatus (they were gathered from Yamandjar, Kyzylkum Desert) was conducted in separate places which were distant from each other on the distance $80-100 \mathrm{~km}$, probably there were separate populations of local nodule bacteria although during expeditions the common habitats of Ammodendron conollyi with Astragalus villossimus as well as the areas of common inhabiting of Ammodendron conollyi with Astragalus unifoliolatus occurred. But it was necessary to collect nodules in places distant from each other in order to have distinct groups of nodule bacteria for their study. If Ammodendron conollyi plant can grow in pure sands and semi-sand soils, then Astragalus villossimus plant grows in poorer dried soils and semi-sand soils, while Astragalus unifoliolatus plant - mainly in pure sands. Therefore, Astragalus unifoliolatus plant has comparatively narrower area of habitat and maybe its low specificity to other plants is determined with this feature.

According to observations of some authors, Astragalus genera form nodules by the $2^{\text {nd }}$ year of their vegetation in natural conditions. At the same time, from expeditional observations of both our botanists and us, the nodules and roots of Ammodendron conollyi were brown and black colors correspondently in natural conditions (in our microvegetation experiments after 2.5 months of growth the initially pink-colored fragile nodules and white roots became dark-brown color; the appearance and development of 2.5 monthly plants of Ammodendron conollyi and Astragalus looked like as 1-2 yearly natural plants). Probably, due to increase of requirements in nitrogen by the $2^{\text {nd }}$ year in natural conditions the plants begin to form nodules that are necessary for intense growth and development of young plants as well as their adaptation to surrounding environmental conditions. The studied strains of desert rhizobia are fast-growing rhizobia, but they are slower than Azorhizobium caulinodans (its generation time is $40-45 \mathrm{~min}$ [22]. They have 2 similar megalpasmids and some of them have additional $3^{\text {rd }}$ megalpasmid, they do not form nodules in alfalfa. Microbiological and molecular-genetic characteristics of rhizobial symbiont of Sesbania revealed the availability of 2 megaplasmids (300 and $450 \mathrm{MDa}$ ), generation (doubling-time) time 2 hours 15 min and capability for growth at $2 \% \mathrm{NaCl}$, sensitivity to antibiotics and capability for nodule formation in Vigna unguiculata [23]. In literature the rhizobia isolated from Astragalus are related to Mezorhizobium [24-26], but at the same time the authors noted that the most of studied rhizobia differed on DNA-homological groups from all known species of rhizobia and one subgroup was a unique genetic line [27]. Other authors on the basis of fingerpriniting noted that rhizobia of Astragalus adsurgens were related to Agrobacterium, Mezorhizobium, Rhizobium and Sinorhizobium genera [28]. During study of rhizobia (Sinorhizobium, Mezorhizobium), which cause nodulation in leguminous tress of Africa and South America, it was noted that there were both similarity and differences in symbiotic determinants of rhizobia [29]. In our investigations it was determined that nucleotide sequence of $16 \mathrm{~S}$ rDNA gene of AC1-1, AC8-1, AC21, AV1, AV3, AU3-1, AV8-1, AV9 and AU30-1 nodule bacteria strains matched by $96-97 \%$ together with analogous genes of Rhizobium sp. GGNM 66 species; the genes of AC15; AU17-1; AU30-2 and AU7 89-97\% were identical to genes of Burkholderia cepacia NBRAJG97 species and genes of AC11 and AV6-1 strains were identical by $95 \%$ and $98 \%$ to the genes from Achromobacter xylosoxidans species. In whole, according to phylogenetic tree the evolutionary origin of studied bacteria is close each other and they belong to both Alpha and Betaproteobacteria classes.

Thus, as a result of conducted work, the conditions for study of growth and nodulation of desert leguminous perennial plants have been chosen and found, the interactions between nodule bacteria and perennial xerophyte tree and shrubs have been determined. On the basis of this it may conclude that model system of efficient nitrogen-fixing symbiosis "nodule bacterium-perennial 
Table 3. Influence of nodule bacteria on nodulation, ARA and yieldness of desert leguminous tree Ammodendron conollyi, leguminous shrub Astragalus villossimus and leguminous semi-shrub Astragalus unifoliolatus.

\begin{tabular}{|c|c|c|c|c|c|c|c|c|c|c|c|}
\hline \multicolumn{4}{|c|}{ Ammodendron conollyi } & \multicolumn{5}{|c|}{ Astragalus villossimus } & \multicolumn{3}{|c|}{ Astragalus unifoliolatus } \\
\hline Strain & $\begin{array}{l}\text { Average } \\
\text { nodules } \\
\text { number }\end{array}$ & $\begin{array}{c}\text { ARA, } \\
\text { ppm } \\
\mathrm{C}_{2} \mathrm{H}_{4} \\
\text { tube/hour }\end{array}$ & $\begin{array}{c}\text { Efficiency } \\
\text { symbiosis, } \\
\%\end{array}$ & Strain & $\begin{array}{l}\text { Average } \\
\text { nodules } \\
\text { number }\end{array}$ & $\begin{array}{c}\mathrm{ARA}, \\
\mathrm{ppm} \\
\mathrm{C}_{2} \mathrm{H}_{4} \\
\text { tube/hour }\end{array}$ & $\begin{array}{c}\text { Efficiency } \\
\text { symbiosis, } \\
\%\end{array}$ & Strain & $\begin{array}{l}\text { Average } \\
\text { nodules } \\
\text { number }\end{array}$ & $\begin{array}{c}\text { ARA, } \\
\text { ppm } \\
\mathrm{C}_{2} \mathrm{H}_{4} \\
\text { tube/hour }\end{array}$ & $\begin{array}{c}\text { Efficiency } \\
\text { symbiosis, } \\
\%\end{array}$ \\
\hline AC1-1 & $5 \pm 2.64$ & $6.91 \pm 0.44$ & 147.7 & AV1 & $18 \pm 2.16$ & $1.72 \pm 0.99$ & 121.5 & AU2-1 & $19 \pm 2.0$ & $0.47 \pm 0.21$ & 62.5 \\
\hline AC2 & $5 \pm 3.0$ & $5.59 \pm 0.25$ & 108.9 & AV2 & $17 \pm 2.16$ & $2.52 \pm 0.73$ & 102.5 & AU3-1 & $41 \pm 5.29$ & $3.33 \pm 0.96$ & 103.5 \\
\hline AC4-1 & $2 \pm 1.73$ & $2.81 \pm 0.63$ & 98.5 & AV3 & $18 \pm 3.26$ & $2.95 \pm 0.77$ & 122.4 & AU4 & $19 \pm 4.58$ & $1.5 \pm 0.51$ & 62.5 \\
\hline AC8-1 & $3 \pm 1.0$ & $2.5 \pm 0.43$ & 143.2 & AV6-1 & $5 \pm 1.0$ & $0.61 \pm 0.27$ & 95.6 & AU7 & $19 \pm 2.64$ & $1.44 \pm 0.78$ & 65.1 \\
\hline AC11 & $4 \pm 1.0$ & $2.34 \pm 0.19$ & 158.2 & AV8-1 & $11 \pm 2.0$ & $0.73 \pm 0.35$ & 122.4 & AU17-1 & $20 \pm 7.54$ & $1.81 \pm 0.71$ & 116.0 \\
\hline AC12-1 & $5 \pm 3.0$ & $6.91 \pm 0.32$ & 143.2 & AV9 & $25 \pm 10.0$ & $2.87 \pm 0.55$ & 123.2 & AU20-1 & $23 \pm 4.58$ & $1.58 \pm 0.45$ & 109.8 \\
\hline AC13-1 & $3 \pm 1.0$ & $2.82 \pm 0.63$ & 108.9 & AV9-1 & $10 \pm 1.63$ & $1.31 \pm 0.65$ & 106.8 & AU23 & $32 \pm 8.54$ & $4.02 \pm 0.52$ & 136.6 \\
\hline AC15 & $4 \pm 1.73$ & $3.2 \pm 0.75$ & 89.7 & AV26-1 & $17 \pm 2.64$ & $1.93 \pm 0.86$ & 104.3 & AU28 & $24 \pm 6.55$ & $1.87 \pm 0.68$ & 136.6 \\
\hline AC18-1 & $4 \pm 2.64$ & $4.67 \pm 0.38$ & 147.7 & AV30 & $19 \pm 3.26$ & $2.25 \pm 0.68$ & 99.1 & AU30-1 & $20 \pm 2.64$ & $4.15 \pm 0.92$ & 151.7 \\
\hline AC21 & $5 \pm 1.0$ & $4.67 \pm 0.67$ & 119.4 & AV36-1 & $20 \pm 2.64$ & $3.13 \pm 0.99$ & 114.6 & AU30-2 & $21 \pm 3.46$ & $1.42 \pm 0.64$ & 121.4 \\
\hline AV1 & $4 \pm 1.0$ & $4.77 \pm 0.57$ & 153.7 & AC8-1 & $15 \pm 5.29$ & $5.64 \pm 0.78$ & 128.4 & AV1 & $32 \pm 4.35$ & $4.41 \pm 0.99$ & 151.7 \\
\hline AV3 & $2 \pm 1.0$ & $2.0 \pm 0.55$ & 134.3 & AC11 & $20 \pm 3.6$ & $3.04 \pm 0.85$ & 114.6 & AV2 & $35 \pm 5.29$ & $3.07 \pm 0.4$ & 139.2 \\
\hline AV6-1 & $4 \pm 1.73$ & $3.93 \pm 0.45$ & 132.8 & AC15 & $29 \pm 5.29$ & $5.44 \pm 0.91$ & 111.2 & AV3 & $27 \pm 4.0$ & $3.26 \pm 0.45$ & 116.0 \\
\hline AV8-1 & $4 \pm 2.64$ & $2.43 \pm 0.7$ & 150.7 & AC21 & $15 \pm 4.0$ & $0.7 \pm 0.44$ & 121.5 & AV6-1 & $28 \pm 4.0$ & $2.46 \pm 0.41$ & 154.4 \\
\hline AV9 & $1 \pm 0.0$ & $1.24 \pm 0.32$ & 134.3 & AC1-1 & $10 \pm 5.0$ & $1.19 \pm 0.61$ & 94.8 & AV8-1 & $35 \pm 9.84$ & $4.66 \pm 0.68$ & 157.1 \\
\hline AV9-1 & $3 \pm 1.0$ & $1.77 \pm 0.39$ & 168.6 & AU17-1 & $12 \pm 5.56$ & $0.86 \pm 0.47$ & 103.4 & AV9 & $26 \pm 3.6$ & $2.77 \pm 0.24$ & 125 \\
\hline AV30 & $3 \pm 1.0$ & $3.03 \pm 0.79$ & 140.2 & AU30-1 & $18 \pm 5.0$ & $1.42 \pm 0.69$ & 80.1 & AV9-1 & $25 \pm 6.08$ & $3.54 \pm 0.54$ & 145.5 \\
\hline AV36-1 & $3 \pm 1.73$ & $1.06 \pm 0.59$ & 92.5 & AU30-2 & $12 \pm 2.64$ & $1.16 \pm 0.82$ & 77.5 & AV30 & $23 \pm 6.55$ & $3.74 \pm 0.55$ & 130.3 \\
\hline Control & - & - & 100.0 & Control & - & - & 100 & Control & - & - & 100 \\
\hline
\end{tabular}

Values are the \pm SE, $n=3$; ARA - acetylene-reductase activity.

leguminous plant” has been created. As components of such ecosystem it is necessary to support the definite moisture $5-7 \%$ and sand availability, scarifying and drainaging agent. Implementation of these conditions approaches functioning of created model ecosystem in order that the latter would be included into desert natural ecosystem.

\section{ACKNOWLEGDEMENTS}

Authors express a deep gratitude to Prof. Herman Lips, Dr. M. Ines M. Soares (Institute for Desert Research Ben-Gurion University of the Negev Sede Boqer), Prof. Eduardo Santero Santurino (Laboratorio Andaluz de Biología Facultad de Ciencias Experimentales, Universidad Pablo de Olavide), Dr. Maria-Hoce and Dr. Luis Carlos (Sevilla University, Department of Genetics and Department of Microbiology) for help in carrying out of microbiological-physiological and molecular-genetic experiments, and also to V.S. Bulatnikov (Central Asia Pediatric Institute, Tashkent) for help in microscopic investigations. These investigations were carried out owing to grant support of Inco-Copernicus Program (4 ${ }^{\text {th }}$ program of the European Union), USAID/CDR/CAR Program.

\section{REFERENCES}

[1] Dart, P.J. (1994) Microbial symbiosises of tree and shrub legumes. In: R. C. Gutteridge and H. M. Shelton, Ed., Forage Tree Legumes in Tropical Agriculture, CAB International, Wallingford. http://www.betuco.be/agroforestry/ Forage\%20Tree\%20Legumes\%20in\%20Tropical\%20Agriculture\%20FAO

[2] Zahran, H.H. (2001) Rhizobia from wild legumes: Diversity, taxonomy, ecology, nitrogen fixation and biotechnology. Journal of Biotechnology, 91(2), 143-153.

[3] Korovin, E.P., Ed. (1955) Flora of Uzbekistan. Publish House of Academy Sciences of UzSSR, Tashkent, 638-640.

[4] Khotyanovich, A.U., Ed. (1991) Methods for cultivation of nitrogen-fixing bacteria, ways of both their obtaining and preparing of preparations on their base (methodical guides). All-Union Institute of Agricultural Microbiology, Leningrad, 33-60.

[5] Hardy, D.W., Halstein, R., Jakson, E. and Buens, R.S. (1968) $\mathrm{C}_{2} \mathrm{H}_{2}-\mathrm{C}_{2} \mathrm{H}_{4}$ assay to $\mathrm{N}_{2}$ fixation laboratory and 
field evaluation. Plant Physiology, 43, 9-13.

[6] Ferris, M.J., Muyzer, G. and Ward, D.M. (1996) Denaturing gradient gel electrophoresis profiles of 16S rRNAdefined populations inhabiting a hot spring microbial mat community. Applied Environmental Microbiology, 62(2), 340-346.

[7] Altschul, S.F., Madden, T.L., Schaffer, A.A., Zhang, J., Zhang, Z., Miller, W. and Lipman, D.J. (1997) Gapped: BLAST and PSI-BLAST: A new generation of protein database search programs. Nucleic Acids Research, 25(17), 3389-3402.

[8] Saitou, N. and Nei, M. (1987) The neighbour-joining method: A new method for reconstructing phylogenetic trees. Molecular Biology Evolution, 4(4), 406-425.

[9] Tamura, K., Dudley, J., Nei, M. and Kumar, S. (2007) MEGA4: Molecular evolutionary genetics analysis (MEGA) software version 4.0. Molecular Biology and Evolution, 24, 1596-1599. http://www.ncbi.nlm.nih.gov/sites/entrez? $\underline{\mathrm{cmd}}=$ retrieve $\& \mathrm{db}=$ pubmed $\&$ list uids $=17488738 \& \mathrm{dopt}=$ AbstractPlus

[10] Collavoli, A., Storti, S., Dell'Amico, C. and Iascone, M.R. (2000) Northern blot analysis with digoxigenin in PCR-labeled probes in research samples from myocardial biopsies. Biochemica, 3, 19-20. http://www.roche-appliedscience.com/PROD_INF/BIOCHEMI/no3_2000/PDF/p1920.pdf

[11] Eckhardt, T. (1978) A rapid method for the identification of plasmid deoxyribonucleic acid in bacteria. Plasmid, 1(4), 584-588.

[12] Priefer, U.B. (1984) Characterization of plasmid DNA by agarose gel electrophoresis. In: Pühler, A. and Timmis, K.N., Ed., Advanced Molecular Genetics, Springer-Verlag, Berlin, 26-37.

[13] Glazer, V.M., Ed. (1972) Big practical course on genetics of microorganisms. Publish House of Moscow State of University, Moscow, 1-25.

[14] Nechaeva, N.T., Ed., (1985) Improvement of desert ranges in Soviet Central Asia. Harwood Academic Publishers, London, 88.

[15] Cubo, M.T., Buendia-Claveria, A.M., Beringer, J.E. and Ruiz-Sainz, J.E. (1988) Melanin production by Rhizobium strains. Applied Environmental Microbiology, 54(7), 1812-1817.

[16] Teketay, D. (1998) Germination of Acacia origena, Acacia pilispirina and Pterolobium stellatum in response to different pre-sowing seed treatments, temperature and light. Journal of Arid Environments, 38, 551-560.

[17] Abulfatih, H.A. (1995) Seed germination in Acacia species and their relation to altitudinal gradient in southwestern Saudi Arabia. Journal of Arid Environments, 31(2), 171-178.
[18] Yakovleva, Z.M. and Mishustin, E.N., Ed. (1975) Bacteroids of nodule bacteria. Publish House Nauka, Moscow, 171.

[19] Gordienko, N.Y. and Yakovleva, Z.M. (1979) Topography of infection threads in root nodules of legume plants. Proceedings of the USSR Academy of Sciences, Series Biologic, 3, 466-471.

[20] Yakovleva, Z.M. (1981) Microstructure of pea nodules upon infectioning by neomycin-resistant nodule bacteria mutant. Mikrobiologiya, 50(3), 528-534.

[21] Newcomb, W., Syono, K. and Torrey, J.G. (1977) Development of an ineffective pea root nodule: Morphogenesis, fine structure and cytokinin biosynthesis. Canadian Journal of Botany, 55(14), 1891-1907.

[22] B. Dreyfus, J.L. Garcia, M. Gillis, "Characterization of Azorhizobium caulinodans gen.nov. sp.nov., a stem-nodulating nitrogen-fixing bacterium isolated from Sesbania rostrata”, Internation Journal of Systematic Bacteriology, vol. 38, 1988, pp. 89-98.

[23] Rana, D. and Krishnan, H.B. (1995) A new root-nodulating symbiont of the tropical legume Sesbania, Rhizobium sp. SIN-1, is closely related to Rhizobium galegae, a species that nodulate temperate Legumes. FEMS Microbiology Letters, 134(1), 19-25.

[24] Wdowiak, S. and Malek, W. (2000) Numerical analysis of Astragalus cicer microsymbionts. Current Microbiology, 41(2), 142-148.

[25] Chen, W.X., Li, G.S., Qi, Y.L., Wang, E.T., Yuan, H.L. and Li, J.L. (1991) Rhizobium huakuii sp. nov., isolated from the root nodules of Astragalus sinicus. International Journal of Systematic Bacteriology, 41(2), 275-280.

[26] Zhang, X.X., Turner, S.L., Guo, X.W., Yang, H.J., Debelle, F., Yang, G.P., Denarie, J., Young, J.P. and Li, F.D. (2000) The common nodulation genes of Astragalus sinicus rhizobia are conserved despite chromosomal diversity. Applied Environmental Microbiology, 66(7), 29882995.

[27] Wang, S. and Chen, W. (1997) A study of taxonomy of Rhizobia isolated from Astragalus sp. Acta Microbiologica Sinica, 37(5), 335-343.

[28] Gao, J., Terefework, Z., Chen, W. and Lindstrom, K. (2001) Genetic diversity of rhizobia isolated from Astragalus adsurgens growing in different geographical regions of China. Journal of Biotechnology, 91(2-3), 155168.

[29] Haukka, K., Lindstrom, K. and Young, P.W. (1998) Three phylogenetic groups of nodA and nifH genes in Sinorhizobium and Mezorhizobium isolates from Lehuminous trees in Africa and Latin America. Applied Environmental Microbiology, 64, 419-426. 